\title{
Governing a future London: the city of any dreams?
}

\author{
Rob Pearce and Mike Raco
}

To be a Londoner is always to take a chance: an instinct that manifests itself, materially, by an enormous addiction to lottery that makes Londoners the chief per capita financial gamblers in the world, and which proves itself, at more significant levels, by their perpetual willingness to take the most improbable human risks. And I believe the spirit of the ugly old indifferent capital encourages the presence of such people; and by its very incoherent informality, enables them to discover one another more freely and happily than elsewhere in our land. (MacInnes, 1962)

As one of the first truly global cities, London has always been shaped by three factors: the structuring forces of the global, continental, and regional politics and economics; the resulting flows of people and ideas into and out of the city and the rapidly increasing degree of connectivity to other cities and related markets. In turn, these forces have been mitigated and managed through the ever-changing relationship between an array of institutions, including political, commercial, and civil society organisations. At different points in history the ability of those living in London to influence and control these institutions, and hence their own growth and prosperity and that of the city, has ebbed and flowed. These actors shaped, and continue to shape, London's political economy according to and in response to global economic, political and social forces. The production and reproduction of the city is a direct result of the production and distribution of goods and services it enables and manages. These are the key to the city's economic competitiveness and social progress. Therefore, the balance of forces between governance, commerce and civil society in the city, and their relative influence on its political economy, shaped its past, and will shape its future. Finally, it is the nature of these forces themselves that has tipped this balance in different directions over the decades. These forces are moulded by Londoners themselves who have always been 'willing to taking improbable human risks' to achieve their goals and who have always lived in a city that has a mysterious capacity to bring them together, 'to discover each other', in their struggle for the soul of the city.

\footnotetext{
How to cite this book chapter:

Pearce, R and Raco, M. 2013. Governing a future London: the city of any dreams? In: Bell, S and Paskins, J. (eds.) Imagining the Future City: London 2062. Pp. 109-117. London: Ubiquity Press. DOI: http:// dx.doi.org/10.5334/bag.o
} 
By the early 1960s the benefits of post war macro-economic policies had produced a city where living standards were relatively high and a greater degree of equality was being achieved than ever before. Economic progress was mirrored by progressive social policy, resulting in the 'swinging London' of the 1960s leading the world in popular culture. The 1970s and ' 80 s brought a contraction in the city, with rising inequality and fractured relationships between governance, commerce and civil society institutions, as they were challenged by the global economic storms. The era of progressive consensus politics ended, to be replaced by a new set of norms founded on visions of a Global City. During the 1990s and first decade of the new century the city felt the full impact of neoliberal western capitalism. This restructured the balance of power within the city's institutional framework, most dramatically represented by the 'big bang' in the financial sector in 1988, placing global commercial interests in the driving seat, in the form of financial services weakening the city's governance and political structures and marginalising civil society.

The structuring forces of the global economy elevated London to the world's leading city. However, the shift in power to global commercial interests meant that the economic growth that followed flowed to very few, increasing inequalities and leaving the city even further divided than the '70s and ' 80 s. The near collapse of the banking system in 2008 proved to be a tipping point in the relationship between governance, commerce and civil society, once again recasting their respective roles in remaking the city. It demonstrated that the current model of economic growth in the city is built on unsustainable foundations. It seems likely that despite the deluded optimism of hyper-globalist writers in the 1990s and early 2000s, an economy based on assumptions of constant expansion is likely to fail.

Between now and 2062, London, therefore, faces enormous governance challenges; and yet political control in the city has long been a source of ambiguity. On the one hand, London is the most governed city in the UK. It has a relatively strong Mayor, powerful state bodies, and a planning system that generates comprehensive spatial policy visions and plans. On the other hand, there are costs in being a capital city. Developments are often large-scale and driven by national, rather than local priorities. There are confusing divisions of responsibility between different tiers of government and the city has experienced a remarkable degree of corporate domination. This has been manifest in both the formal political sphere, in which the Corporation of London has become a vociferous voice for global business interests, and in the changing nature of the city's welfare services and infrastructure, large parts of which are now under the control of private companies, and outside of the direct control of government agencies. The political governance of the city, and the city's political class, has become increasingly distant from the communities it purports to serve. There are also questions over the extent to which London's social changes are sustainable in the long run. It is a city with long traditions of political diversity, radicalism and activism and the sheer plurality of its communities in social and economic terms, poses real challenges for future cohesion. Throughout its history it has been a focus for resistance movements, political protest, and violence. If current trends towards polarisation continue, it seems likely that there will be degree of 'backlash', in whatever form, with obvious implications for governance and democracy. The attributes MacInnes (1962) attaches to London provide some insight into this. In highlighting aspects prevalent in the 1960s that have become even more relevant to the contemporary city and its future, they provide an important additional perspective to the lens we will use to observe the city in 2062.

In this chapter we outline and discuss three alternative scenarios for the governance of the city over the next fifty years. We explore the first possibility that the problems highlighted by sustainability writers are overcome, and that the current model of globally-oriented growth continues. The result will be increased polarisation and rising inequalities. We will witness what Colin Crouch (Crouch, 2011) terms the growing corporatisation of public life in which the city's politics, welfare systems, and development trajectories become increasingly shaped by the activities of a post-political, post-democratic corporate elite. A second scenario is one of neo-Keynesianism, founded on the re-nationalisation and public acquisition of private interests in the name of a wider 'public interest'. We discuss the implications that this would have for the governance of the city and the likely position 
of elite groups of professionals and elected politicians. A third scenario is that a middle way emerges, in which a London of 2062 has been created via a new consensus capitalism - one which focuses on the relationships between societal and economic progress to create growth. We consider what would happen if capitalism were to be re-formatted using the concept of 'Shared Value', as developed by Michael Porter and Mark Kramer (Porter \& Kramer, 2011). This might result in a reformed urban political economy, as a product of broader global struggles between political, commercial, and civil society institutions and actors. Global cities, such as London, will act as a battleground in which ideas over the future shape of societies and economies will be fought over. The chapter concludes with a summary of the key points made in these sections and an acknowledgement of some of the wider governance challenges that future citizens and policy-makers will face.

\section{The post-political city of the future and the corporatisation of London's public life}

There is a real possibility that existing trends will continue into the future, and that over the next fifty years London will become an archetypal post-political city characterised by elite domination, social polarisation and divisive development. Since the early 1990s, city planning has essentially been concerned with the management of growth, and the sustainability of globally successful industries. Spatial policy has been used to try and ensure that some of the benefits of expansion reach poorer communities and neighbourhoods (Imrie et al, 2009). This dominant consensus has limited the articulation of meaningful alternatives and discussions over the type of city that London's citizens really want, and/or how these visions could be brought to fruition. In Ranciére's (2003) terms, it has been used to stifle formal political debate so that 'whatever your personal commitments, interests, and values may be, you perceive the same things, you give them the same name. The result is that 'the only point of contest lies on what has to be done as a response to a given situation...so that [there] is a dismissal of politics as a polemical configuration of the common world' (paragraph 6).

The limitations of this way of thinking for social and economic justice have been evident, for at the same time as these post-political agendas of global 'success' have been rolled out, inequalities and social tensions have been expanding at a rate not seen since the early days of the industrial revolution. During the period 1996-2007, overall growth in UK GDP was $37.4 \%$, yet remarkably only $0.7 \%$ of the population saw a growth in their incomes equal to or exceeding this (Murphy, 2011). By 2003 the top $10 \%$ of wealth earners owned $71 \%$ of the wealth and this is likely to be seriously understated as a result of the considerable shift in wealth offshore' (p.101). Most of these elites reside in London, where the poorest $50 \%$ of the population have less than $5 \%$ of the city's wealth, whilst the richest $10 \%$ possess $40 \%$ of income wealth, $45 \%$ of property wealth, and $65 \%$ of financial wealth (MacInnes \& Kenway 2009). Similar patterns are evident in terms of health inequalities, land ownership, access to housing and employment and a plethora of other socioeconomic measures. They constitute the backdrop to the serious riots of 2011 and rises in crime and insecurity across the city. Unless there are significant forms of intervention and/or the economic system changes in structural ways, then it is likely that polarisation will continue to expand at a growing rate.

One additional aspect of post-political governance is its corrosive influence on the democratic process. In the name of enhanced 'efficiency', or what Tony Blair referred to as a principle of 'what matters is what works', state resources and service provision have been handed over to private operators and international investors on a previously unimagined scale. Since the mid-1990s this has resulted in global corporations taking over an expanding proportion of London's welfare assets (Raco, 2012). New forms of elitism have been established in which powerful private sector investors benefit by 'securing irrevocable contractual claims over taxation revenues that they will manage henceforth in their own private companies which they claim will undertake the tasks of the state so much better than the state could do itself' (Murphy, 2011). For Colin Crouch (2011), 
governance is therefore becoming increasingly dominated by global corporations who have the resources to acquire contracts and colonise a greater share of government activity. Much of London's new welfare infrastructure, such as its hospitals, has been provided under long term and hugely expensive Private Finance Initiatives in the name of policy 'efficiency'. The city has received $45 \%$ of all capital spending on PFI projects, making it by far the biggest recipient of any city in the UK (Musson, 2008). This will have a disruptive impact over the coming decades, as local managers desperately try to balance long-term asset payments with short-term budgetary pressures and demands. Many of the PFI contracts will still be in existence in the 2040s.

So by 2062 London may have become a post-political city. If current trends are sustained, its global industries will continue to dominate its economy, its politics, and its social order. This will be underpinned by a dominant consensus in which discussions over alternative ways of governing will be tightly framed, and policy 'innovations' will be limited to a series of piecemeal interventions, designed to tackle only the most severe problems and pockets of deprivation. Opposition will be managed and controlled, as political decisions become removed from the remit of political debate, and transferred to private companies who govern behind opaque contracts to impose quiet and ruthless forms of management efficiency. The role of the Mayor and other political actors becomes one of an 'intelligent client', seeking to manage the activities of private operators, who effectively determine how state services should operate and for whom. The city will continue to witness the residualisation of social exclusion, poverty, and inequality as core political concerns. The existence of structural inequalities will be blamed on crude understandings of individual and community (ir)responsibility. Little or no effort will be made to change the fundamental character of the city's economic base which continues to act as a vehicle for transferring wealth and resources from the majority to the affluent, and increasingly mobile, minority.

\section{The rise of a neo-Keynesian London and the revival of urban government}

The financial crisis may be the prelude to a very different form of development politics in London and beyond. The dominant assumptions that have characterised neoliberal and hyper-global visions may be breaking down under the weight of failure and the very real limits imposed by environmental constraints. Rather than generating a long-term revival of such models, the current moment offers new opportunities for the development of alternative agendas and ways of thinking to take centre stage. New narratives and descriptions of what future development should look like are beginning, albeit tentatively, to emerge, perhaps most explicitly in the writings of authors such as Tim Jackson (2011) with his recent manifesto for Prosperity Without Growth, or Ha-Joon Chang's (2011) alternative agendas for future economics. It is, therefore, possible to imagine that by 2062 London will have become a showcase for a neo-Keynesian revival with states once again taking a direct, interventionist role in shaping social and economic affairs.

This could take on a variety of forms. To begin with, the contradictions and costs associated with privatisation may have triggered a renewed desire for coordination and the re-creation of top-down forms of bureaucratic governance and management. Such an approach could, at the very least, see the implementation of programmes of nationalisation of key economic sectors and welfare services. Governance may be replaced by government, as states look to take greater control over the management of cities and populations in response to the rather chaotic and fragmented structures that have emerged in the wake of neoliberalisation. There may be a rediscovery of the public realm and lively discussions over what might constitute the public interest in London. As Marquand (2004), and others, have long argued, under neoliberalism it has become increasingly difficult to articulate a political agenda that promotes public intervention as a vehicle for the creation of better cities. A reformed politics may see the revival of such agendas and the empowerment of public professionals to take greater control over key assets and industries. 
It would also provide a partial solution to the growing malaise that exists in London and elsewhere in the UK towards formal democratic and state-led institutions. Empowered public sector bureaucracies could provide an important focus for the mobilisation of political agendas, as politics would once again matter. It would 'make a difference' whether or not politicians of different views were elected, as their programmes would have the capacity to actually re-shape the city, re-order how it functions, and change the day-to-day lives of its citizens. This could act as a catalyst for democracy and arrest the 'post-political' erosion of public debate and political life that the city has suffered.

Neo-Keynesian principles would also change the relationships between communities within London, and between the city and the rest of the national economy. A re-invigorated planning system would involve a renewed emphasis on spatial justice, and seek to ensure that London's aggregate economic growth would be redistributed more evenly, both within and outside of the city. This would, of course, meet with stiff resistance from business groups, and others, for whom any attempt to restrict economic growth in the capital would undermine its longer-term resilience (Raco \& Street, 2012). Others, however, have called for a de-centring of the UK economy and the cultural dominance of London and the South Amin et al, 2003; Imrie et al, 2009). The city is criticised for being parasitic, rather than propulsive, and any serious neo-Keynesian approach would look to find ways of increasing the contributions made by its financial service industries, and wealthier individuals, and use the welfare system to redistribute resources to areas and communities of need. Again, the implications of this for London could be enormous, and in large part depend on how the global economy evolves in the coming decades.

Moreover, in a neo-Keynesian London some of the problems associated with the city's past may re-assert themselves. The transfer of the city's assets to state bodies may not necessarily generate new forms of collective ownership. Traditionally in some policy fields, such as health care and housing, Keynesianism of the past led to the concentration of decision-making power in the hands of professionals and experts which, in some places, created distant, top-down forms of administration and decision-making. Vulnerable groups such as those with physical impairments and/or the elderly suffered particularly badly under monolithic welfare structures (Oliver, 1990). As Milewa et al (2008) have shown, post-war welfare organisations were often deliberately insulated from political criticisms and community-led protests. Neoliberalism emerged in a context where authors from the political left, as well as the right, were attacking the growth of state bureaucracies for their detached and opaque structures (Gough, 1979; Offe, 2003). An enormous amount of social research on power elites, and modernist planning practices, in the post-period also laid bare the sexist and often partisan nature of some public sector bureaucracies in the wake of nationalisation (Saunders, 1979). It may become more difficult for community and third-sector groups to get their views heard. New forms of political closure could be enacted, based on paternalist forms of governance. If poorly managed, then many of the gains made through community activism in recent decades could be reversed.

\section{A London of shared and common value}

In this final section, we imagine that a third scenario emerges based on a reformatting of capitalism. It emerges through a new urban political economy that takes place as a result of global struggles and conflicts in which London, and other global cities, provide battlegrounds for the articulation of different future visions between political, commercial and civil society interests. However this struggle does not end in complete or simple victory for either capital or labour. London in 2062 has been created via a new form of consensus capitalism: one which focuses on the relationship between societal and economic progress to create growth. In 2012 this was best represented by the concept and principles of 'Shared Value' (Porter \& Kramer, 2011), and in this section we discuss what the implications of what such an outcome might lead to. 
The ability to accept and connect with 'the other' when combined with the will to succeed is what has shaped the city over centuries and is what created the London of 2062 . How these attributes impact on the behaviour and interaction of the political and governance, commercial and civil society institutions and the actors who make and remake the city, shapes London's destiny. In turn, it also shapes other cities, hardwired into the global city network. As Porter stated in 2012 'at a very basic level the competitiveness of a company and the health of the communities around it are closely intertwined' (Porter \& Kramer, 2011). In 2062 the ability of Londoners to take a risk, and to accept and connect to others, no matter their background or origin, has resulted in a new institutional framework for commerce and civil society, where economic competitiveness and social progress are not just intertwined but interdependent. A new political economy of shared value has been born.

We imagine that a London of shared value in 2062 is really a product of the global uprisings that started with the Arab Spring of 2011, and the Global City Uprisings that will emerge in the coming decades. It is not difficult to imagine that the ever increasing connectivity London shares with other key cities across the world, the widespread use of technology and social media and the production of the best educated young urban generation (via the investment in education between 2000 and 2010), will give rise to a new movement that eventually reshapes, not only civil society, but governance and commerce structures. London will become a crucial node in a network of 'City Uprising' social movements, made up of well-educated consumers as well as the disenfranchised and disconnected. These groups were prepared to risk challenging the oligarchy (the socalled 'feral elite') previously created between commercial and governance interests, driven by the realisation that the levels of inequality and unsustainable urban living were a direct product of the urban political economies, operating in global cities, controlled by these interests. The City Uprising movements reformed civil society in London as well as other global cities, establishing a broad set of common values centred around trust, transparency, social solidarity, moral purpose and civic action, aimed at reclaiming some of the processes by which 'their' city was produced and reproduced. Global connectivity allowed individual actors sharing these values and behaviours to become linked, as previously global capital had become, creating a strong and distributed civil network, capable of challenging the institutional status quo, whilst remaining rooted in the communities they grew out of. The impact resulted in civil unrest and struggle for many years as London, and other global cities, convulsed in the wake of huge economic instability. Political, commercial and governance institutions were destroyed and remade in response. However, the result by 2062 was not what was predicted.

As the financial sector's political and economic power and influence dwindled, London's global technology, green manufacturing and utility and service industries took centre stage. Clearly distancing themselves from the socially unacceptable commercial behaviours of 'big business' (seeing the competitive advantage in doing so), and so new, or emergent, as not to be tied to the previous discredited oligarchy, a new commercial institutional framework evolved in London and other global cities. It represented a reformatting of capitalism, and its relationship with the consumers it depended on and the communities it was based within. These approaches began to pursue economic competitiveness and social progress at the same time. This new institutional framework enabled commercial interests to seek new markets in the developed, as well as undeveloped, world, seeking competitive advantage and increased market share through the adoption of shared value approaches. This new breed of global commercial operation created new institutional approaches, seeking to create additional economic and social value, by connecting more closely with the communities they were situated within as well as their customers; developing local supply chains, to reduce costs and build resilience into production; creating new relationships with local consumers, to create new products and enter new markets; and reengineering their value chains, exploring new ways of delivering, including increasing local social investments and developing new forms of private/social ownership. This new set of priorities, linked to their profitability, created new institutional links between commercial and civil society interests built on shared moral, ethical and civic values as well 
as the creation of shared economic and social value. This new form of capitalism not only embraced the civic and moral values of City Uprising, it inculcated it into its own DNA.

These new institutional models, created in London through the disruptive and anarchic convulsions of the 2020s, were adapted and adopted throughout the major global cities, where the corresponding commercial and civil society institutions - now more interconnected than ever before - responded to the structuring forces unleashed in London and other major cities by creating similar forms of business model and ownership, fusing commercial interests and the civic interests of City Uprising. This radically changed the processes of the urban political economy, through the dynamic tension between commercial, governance and civil society interests.

This reformation of capitalism resulted in the reformation of the urban political process, and vice versa. London's ability to foster 'risk takers' and 'chancers', coupled with its incoherent informality, created the conditions for this dramatic reformation. City Uprising presented the touchstone for those willing to take a chance and challenge the neoliberal elite, just as deregulation and privatisation had offered the same chance to commercial interests to challenge the consensus in the 1980s. This resulted in a realignment of governance, commercial and civil society institutional frameworks, increasingly driven by a shared vision of civic culture, common purpose and social solidarity. London in 2062 has been created via a new 'consensus capitalism' - one which focuses on the relationship between societal and economic progress to create growth. The line between civil society and commerce has become blurred, creating new institutions, organisations and arrangements focussed on shared moral, ethical and civic values as well as the creation of shared economic and social value.

\section{Conclusions}

Whatever course the global economy takes over the coming decades, it is clear that London will be faced with a number of competing challenges for control of the city. In this chapter we have provided a lens through which to imagine these changes, set out some of the political economic possibilities that may emerge and some potential directions of change. We have argued that as a premier global city, London will be at the receiving end of changes in the global economy, but will also act as a centre for change and influence well beyond its borders (Massey, 2007). There are other factors that we have only touched on, including environmental change, the city's demographic future, and technological innovations. The wider political environment is also subject to enormous uncertainties, and while we have tried to adopt an optimistic tone in the discussion here, there are other trends in existence that raise altogether more worrying future prospects. For example, parties of the Far Right are becoming increasingly powerful across the European Union (EU), and some of the assumptions over the free movement of people and trade that have underpinned London's economy and changing social make-up may be a product of their time. Recent discussions in the EU over the 'reception capacities' of places, and the use of borders to manage migration flows, represents one possible future that will have significant implications for London Raco \& Tasan-Kok, 2010).

Notwithstanding these wider changes, we have also argued that institutions matter, and that it is essential that government bodies and civil society organisations have the capacities and resources to implement programmes of action. This means strengthening existing structures where they work effectively and reforming and creating new ones when required. We disagree with authors, such as Beck (2008), for whom territorial state-systems have become 'zombie categories', with little substance in a cosmopolitan, post-national world. Institutions still act as a focus for political demands, and in our discussion here, we have outlined ways in which they can be reformed to change the form and character of governance in the city. In outlining some of Porter and Kramer's (2011) ideas on shared value, we have suggested what an alternative form of capitalism might look in future, 
brought about by political, economic, and social upheavals. Current models, we argue, are unsustainable, although it is possible to imagine the emergence of a divided, post-political city in which a tiny minority govern in their own interests. A return to neo-Keynesianism is, perhaps, unlikely in a context of austerity governance, but it is possible that the failure of existing systems might precipitate a return to earlier modes of government intervention, and renewed concern with direct social and spatial redistribution. Whatever path the struggle for the city takes, it is likely that it will continue to be influenced by the intangible attributes of Londoners described by MacInnes (1962); the ability of the city to nurture and bring together risk-takers who are prepared to take radical action that continually makes and remakes the institutions that shape the city. London has long been a city of extremes, with a cultural and symbolic significance all of its own. History shows that what happens in the city in the next fifty years will have a resonance long into the future.

\section{References}

Amin A, Massey D. and Thrift N. 2003. De-centering the Nation. A Radical Approach to Regional Inequality. London: Catalyst

Beck U. 2008. World at Risk. Cambridge: Polity Press

Chang H-J. 2011. 23 Things They Don't Tell You About Capitalism. London: Penguin

Crouch C. 2011. The Strange Non-death of Neo-liberalism. Cambridge: Polity Press

Gough I. 1979. The Political Economy of the Welfare State. Basingstoke: Palgrave, MacMillan

Imrie R, Lees L. and Raco M. 2009. London's regeneration. In: Imrie R, Lees L. and Raco M, editors. Regenerating London: Governance, Sustainability, and Community in a Global City. London: Routledge. p. 3-23.

Jackson T. 2011. Prosperity Without Growth. London: Earthscan

MacInnes C. 1962. London: City of Any Dream. London: Thames \& Hudson

MacInnes T. and Kenway P. 2009. London's Poverty Profile. London: New Policy Institute

Marquand D. 2004. Decline of the Public. Cambridge: Polity Press

Massey D. 2007. World City. Cambridge: Polity Press

Milewa T, Buxton M. and Hanney S. 2008. Lay involvement in the public funding of medical research: expertise and counter-expertise in empirical and analytical perspective. Critical Public Health. 18: 357-366.

Murphy R. 2011. The Courageous State - Rethinking Economics, Society, and the Role of Government. London: Searching Finance Ltd

Musson S. 2008. Public-Private Partnership and the Geography of the State. Presented: Association of American Geographers Annual Meeting 15th-19th April 2008. Boston

Offe C. 2003. The Contradictions of the Welfare State. Cambridge: Polity Press

Oliver M. 1990. The Politics of Disablement. London: MacMillan

Porter M. and Kramer M. 2011 (January-February). Creating Shared Value. Harvard Business Review. Available from: http://www.hks.harvard.edu/m-rcbg/fellows/N_Lovegrove_Study_ Group/Session_1/Michael_Porter_Creating_Shared_Value.pdf. [Accessed 07 August 2013]

Raco M. and Tasan-Kok T. 2010. Competitiveness, cohesion, and the credit crunch: Reflections on the sustainability of urban policy. In: De Boyser K, Dewilde C, Dierckx D. and Friedrichs J, editors. Between the Spatial and the Social. Hants: Ashgate Publishers

Raco M. 2012. The New Contractualism, the Privatisation of the Welfare State, and the Barriers to Open Source Planning. Planning, Practice, and Research. In press

Rancière J. 2003. Comment and Responses. Theory \& Event. 6(4): 1-28

Raco M. and Street E. 2012. Resilience Planning, Economic Change and the Politics of Post-recession Development in London and Hong Kong. Urban Studies. 49(5): 1065-1088.

Saunders P. 1979. Urban Politics - A Sociological Approach. London: Penguin 


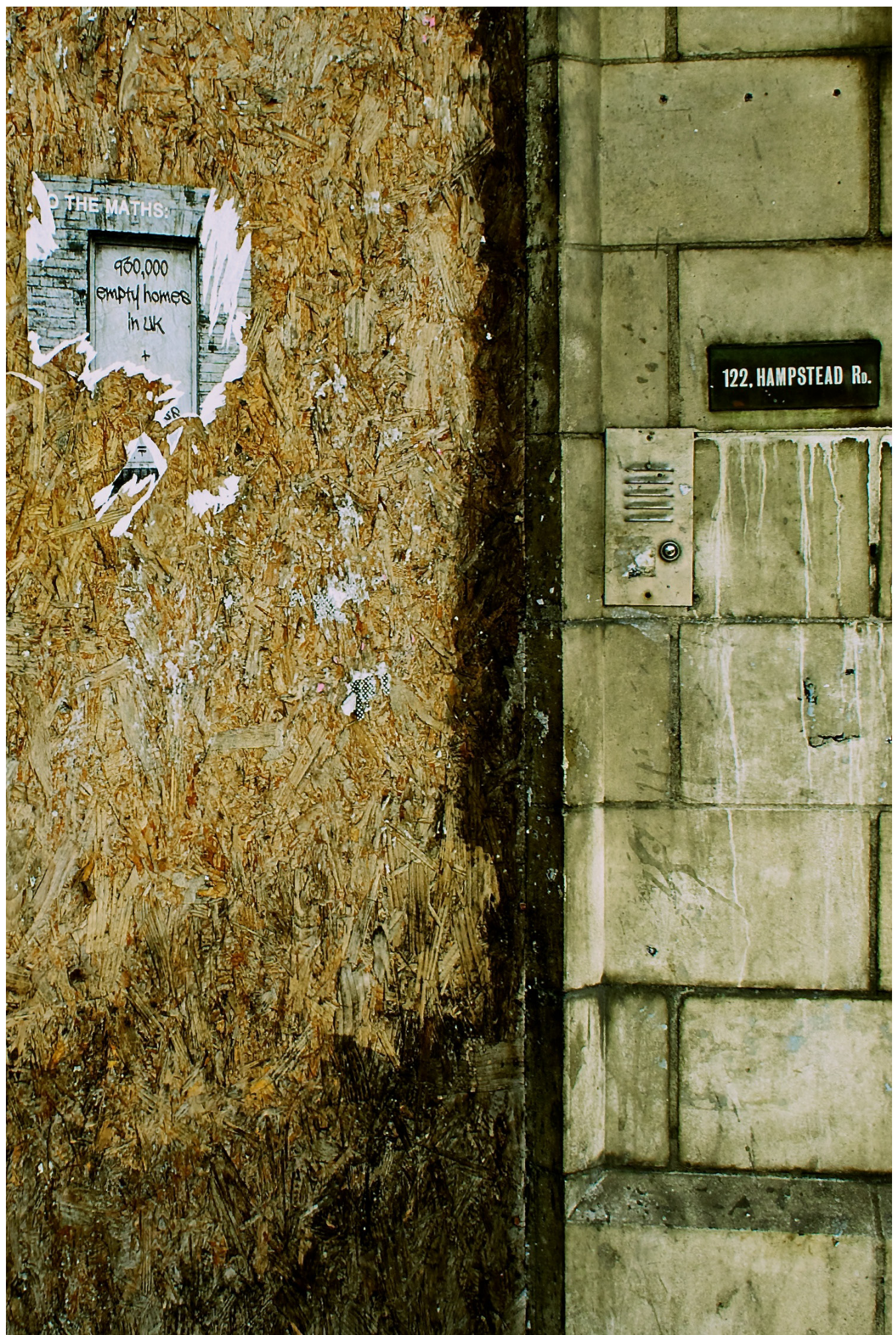

